\title{
Study on the Development Mode of Engineering Project Management in China
}

\author{
Mengjiao Zhou \\ ( born in may, 1983 ), female, native place: Enshi, Hubei, master candidate, associate professor, \\ research direction: engineering project management. \\ College of Mobile Telecommunications Chongqing University of Posts and Telecom
}

(Chongqing ,China 401520)

Keywords: Engineering project management; Development; Model

\begin{abstract}
Engineering project management mode is very important for real estate developers in our country, it relates to if the whole project can guarantee the quality and timely completion, and different types of the project management mode are also different. This paper briefly introduces the engineering project management and project management mode, and it puts forward some problems existing in the current engineering project management in our country, and looks forward to the development trend of engineering project management in our country.

With the rapid development of China's market economy, more and more large-scale construction projects are also being carried out. Since China's accession to the WTO, the influx of a large number of international talent led to the domestic and international engineering market competition which is becoming larger and larger, and it also promoted the project management mode of our country that must also advance with the times in order to improve competitiveness. Because of the different backgrounds at home and abroad, when the domestic study international project management knowledge, it also produced some inevitable problems in the selection of the project management model. How can we absorb the advanced project management knowledge, but also to avoid or solve the errors in the project, which is the problem that our generation of architects should solve.
\end{abstract}

\section{Brief Introduction of Engineering Project Management}

Engineering project management refers to the project management enterprises entrusted by the owner, according to the contract agreement, on behalf of the owners of the project organization and implementation of the whole process or some stages of the management and service[1]. The project management enterprise does not directly contract with the general contracting enterprise of the project or the enterprise of investigation, design, supply, construction and so on. But according to the contract agreement, to assist the general contracting enterprise owners and project or survey, design, supply, construction companies signed a contract, and commissioned by the owners to fulfill the contract engineering supervision. The specific management methods and the content of services, authority, fees, responsibilities and so on, by the owners and project management companies to develop and negotiate and form a written document for archiving. According to the contract between the owner and the project management enterprise, both the functions and objectives of the project management are different.

\section{Management Mode in engineering Construction Project}

With the rapid development of social economy, the demand on engineering construction are constantly changing, how to simplify the management work, and can get a more comprehensive and efficient services, to achieve the target better, which requires the continuous improvement and development of construction project management mode. Common engineering construction project management modes are as follows:

DBB mode. DBB model is familiar with the traditional project management model that is design bidding construction in the international comparison of a common management model. This model is carried out by the owner of the feasibility study and other preliminary work, and the project will 
be evaluated after the establishment of the design in the design phase of the preparation of tender documents, and then through the tender to determine the contractor. After the signing of the contract, the owner shall have the right to supervise and manage the subcontracted parts of the project. The technical basis of the model management is the current order method, so it takes longer.

DB mode. DB model is the design - build mode, the international calls it as the "turnkey" model, which is known as the general contract, and it is a more concise project management model [2]. Using this management mode, the owners only need to select a company responsible for the design and construction of the project, the owners of collaboration and the general contractor can complete the project planning, design, cost control, schedule and so on. This model avoids the contradiction between design and construction, which significantly reduces the cost of the project and the construction period to ensure the quality of the project can be improved.

CM mode. CM mode is the construction management mode, namely in the construction by fast path method, from the initial stage and has experience in the construction of CM company, which is convenient for designers to provide advice on the construction and construction process that is responsible for the management of the whole project construction. This model breaks the traditional model of the first design and then tender, episode stage contract, set owners, CM and design units as a whole, responsible for the organization and management of the project planning, design and construction. The advantage of this model is that it can shorten the duration of the project saving the cost of the project construction investment to reduce the investment risk and get an early return.

DM mode. The DM model is the design management mode, which is a kind of project management mode being similar to the CM model, but it is more complicated. In this mode, the owners no longer need and different construction design and construction units signed a service contract, but as long as both signed a design similar to CM services, including contract. This kind of management mode is more common in foreign project management.

BOT mode. BOT build - operate - transfer mode refers to the government opening up its infrastructure construction and operation of the market to attract foreign capital, and the item company awarded the concession by the company responsible for the financing and organization construction matters and operation after the completion of the project which is responsible for the loan repayment that will be handed over to the government when the project in the concession expires. This management model is commonly used in the construction of transnational projects.

EPC mode. EPC model is the design - procurement - construction mode, the design of this mode in addition to the specific design work, but also may include the overall planning of the project as well as the implementation of the organization and management of the planning and specific work. Using this mode, the owners only need to provide investment intentions and requirements, and the rest of the work by the EPC contractor completed by the owners. And only their own or delegated management of the project, which means no supervision unit contract by reducing the cost of the contractor. The design risk, natural risk, unforeseen difficulties and risks. EPC contract general should be the lump sum contract. This model is suitable for large scale, long duration, and complex engineering, such as factories, power plants, oil development and other basic civilian facilities.

Partnership mode. This kind of management mode first appeared in the United States, it is a management mode based on the full consideration of the interests of investors to determine the common goal of the construction project. The parties reached a short-term or long-term agreement based on mutual trust and sharing of resources, establish working groups to cooperate with each other, and timely issues in communication can avoid disputes appearing to solve the construction problems in the process of implementing the project, risk sharing and possible costs associated with which to ensure the realization of goals and interests of participating parties. This management mode is generally used in conjunction with other management modes.

Project control mode. This mode is suitable for large-scale and large construction project owner management decisions that need to be produced, and it is a product of engineering consulting and information technology integration, and its core is to project the results of information processing flow guidance and control engineering material flow. The project is essentially a decision support 
mechanism of construction project owner, which means project control mode can not replace the conventional construction project management as an independent mode, but it often coexist with other management modes.

\section{Current Problems in the Engineering Project Management in China}

Engineering project management legal system is not perfect. The engineering construction project in our country is affected by the planned economy for a long time, which led directly in the construction of the project that does not want to use any kind of effective approach to the management of the project management, we agreed that everything will be fine as long as the technical clearance, and management is a form of things without much attention. Until now, there are many so-called experienced construction leaders who have yet to have a deep understanding of the management advantages, no relevant project management documents of the project are generally taken by the construction contractor and subcontractor manner. The most important is in the engineering construction not on project management put forward corresponding specifications and requirements from the legal system, the safety of construction personnel can perfunctory for safety and environmental protection configuration used in the site which can be saved. [3]

Project management organization system is not perfect. The establishment of a lot of project management organization is to cope with the government inspection and temporary, even if there is such a management organization, most is not the site management and construction experience, but also unable to project management for the corresponding experience accumulation and inheritance. In addition, the engineering management of our country is the owner's own management, and some of the common management mode can not be effectively distinguished and utilized. Most of the members of the management structure only pursue the "specialization" in writing, but it can not apply the existing management knowledge to the practice of engineering construction project management.

Do not attach importance to the feasibility study of the project. The feasibility study of a project is very important, which means it is important for investors wether to invest in the project, but also for the project in the construction process may involve all aspects and provides an important reference. Many of the domestic construction projects are lack of feasibility study of the project, and most of them are a head of blind investment, resulting in economic losses, but also detrimental to the construction of the project. For example, our country will often appear uncompleted residential flats such an example that is a serious lack of the feasibility study of construction projects.

\section{The Development Trend of China's Engineering Project Management Modes}

In view of the above analysis of the current problems in the engineering project management in our country, this paper puts forward the following points of the development of China's engineering project management modes.

Engineering project management develops to international. Nowadays, China's economy has been fully carried out in the global economic market involving more and more international engineering projects, which requires the internationalization of China's engineering project management. Because the engineering project management in our country is started late compared with foreign development, and there is not a small gap in investment, personnel, management and services, and foreign enterprises will use the technology and management advantages occupy the market of our country. Therefore, China should keep pace with the times in the project management improving the level of enterprise project management to study the construction of advanced technology, and strive to achieve gratifying achievements in the international project management market.

Engineering project management information. Since entering the digital era, the application of computer information technology in construction project in China is becoming more and more popular, and all kinds of application software and project management related also gradually 
developed which plays a very important role in the daily management work. All decision makers daily project management in the construction site to obtain large amount of dynamic information, and then according to these information timely and effective adjustment of the progress of the project, which is in the previous management is not able to do. Therefore, the combination of engineering project management and computer information technology is the inevitable trend of modern project management.[4]

Whole process of engineering project management. The process of engineering project construction in our country is staged, and the whole project is divided into several stages which are completed by different parts. Each department is too independent with lacking of communication that is not conducive to the overall development of enterprises. The enterprise live gradually by managing the transition to independent government commissioned engineering consulting regulatory bodies and it plays a coordinating role of the various stages of the scene which also let the owners to keep abreast of the progress of the project and the existing problems, so that the owners can control the construction project for the whole process. [5] This is also a manifestation of the trend.

In summary, the construction project cannot do without the excellent project management team, and good project management team cannot do without the reasonable mode of project management, and project management mode has advantages and must be consistent with the type of project. Therefore, we must always enrich own professional and technical and management knowledge in order to better use the existing management model for the construction project reasonable and effective management. 


\section{References}

[1]Yafeng Yue.Present situation and development trend of engineering project management mode in China[J].Shanxi Architecture, 2009.

[2]Jie Gong.Research on the application of international engineering project management mode in China[D].Chongqing University, 2010.

[3]Shen Zhongjie.On the present situation of construction project management in China [J]. Modern decoration (Theory). 2012 (11)

[4]Yue Yue.The present situation and development trend of engineering project management model [J]. Shanxi architecture. 2009 (15)

[5] Lin Bin.Study on the management mode and incentive measures of engineering project [J]. Science Chinese. 2015 (09 